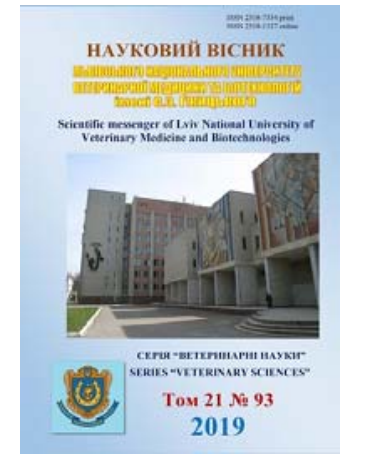

\author{
Науковий вісник Дьвівського національного університету \\ ветеринарної медицини та біотехнологій імені С.3. Гжицького. \\ Серія: Ветеринарні науки \\ Scientific Messenger of Lviv National University \\ of Veterinary Medicine and Biotechnologies. \\ Series: Veterinary sciences
}

ISSN 2518-7554 print ISSN 2518-1327 online doi: $10.32718 /$ nvlvet9304

http://nvlvet.com.ua

UDC 619:612.015.3:612.129:636.4

\title{
Metabolic profile and content of the connective tissues' biopolymers in the blood serum of service boars at the different regime of reproductive loading
}

\author{
O.P. Timoshenko ${ }^{1}$, G.V. Vikulina ${ }^{1}$, D.V. Kibkalo ${ }^{1}$, I.G. Moraru ${ }^{2}$ \\ ${ }^{1}$ Kharkiv state zooveterinary academy, Kharkiv, Ukraine \\ 2 “Agroinvestgroup", Odessa, Ukraine
}

Article info

Received 19.01.2019 Received in revised form 27.02 .2019 Accepted 28.02.2019

Kharkiv state zooveterinary academy, Mala Danilivka Dergachi district, Kharkiv region, 62341, Ukraine. Tel.: +380(5763)57-473 E-mail:vgv.14.vet@gmail.com diagnost_96@gmail.com

"Agroinvestgroup", Odessa region, Odessa, Primorsky district, Fransuzky Bulvar, 66/1, 65009, Ukraine.
Timoshenko, O.P., Vikulina, G.V., Kibkalo, D.V., \& Moraru, I.G. (2019). Metabolic profile and content of the connective tissues' biopolymers in the blood serum of service boars at the different regime of reproductive loading. Scientific Messenger of Lviv National University of Veterinary Medicine and Biotechnologies. Series: Veterinary sciences, 21(93), 21-26. doi: 10.32718/nvlvet9304

It is necessary to carry out not only the evaluation of sexual activity of breeder boars and the quality of their sperm, but carefully investigate the metabolic status by laboratory methods during the medical examination. It helps to determine the optimal parameters for the implementation of the reproductive potential of the breeder boars. Biochemical methods of research can establish imbalance in metabolism, the nature and localization of cytolytic processes by the degree of enzymes activity in serum. However, in order to detect inflammatory or destructive changes in the connective tissue structures, in particular the musculoskeletal system, the most informative indexes will be biopolymers of the connective tissue - glycoproteins and proteoglycans. The results of a complex examination of clinically healthy breeder boars with different regime of their production use, which includes an extended set of biochemical tests with the determination of glycoprotein, chondroitin sulfate, total glycosaminoglycans and their fractions, are presented in this paper. It was found that the level of such parameters as the total protein and its fractions, urea, aspartate and alanine aminotransferase activity, and the $M B$ fraction of creatine phosphokinase did not have any significant differences. For breeder boars that were used in reproductive events irregularly (group I), there was an indicative higher level of creatinine and glycosaminoglycans. In animals with regular use as the herd (group II), the level of creatinine and fractions of glycosaminoglycans (GAG) was lower, but there was an increasing in cholesterol, $\beta$-lipoproteins, and activity of total creatine phosphokinase. The probable difference in these indicators can be explained by the difference in the intensity of the energy metabolism processes in muscle tissue. Indeed, during long-term hard work of skeletal muscles, not only glycogen stores are used, but also the use of lipids is of great importance. In addition, the raising of cholesterol and $\beta$ lipoproteins may be due to their active involvement in the synthesis of steroid hormones. Increasing the activity of total creatine phosphokinase in blood serum of animals with the intensive use in technology probably is the evidence of severe physical activity and the development of destructive processes in muscle tissue (hyperenzymemia is detected in early stages of myopathy). The absence of the most inflammatory processes was evidenced by the unchanged level of serum glycoproteins, which are known as the acute phase tests. Differences in the parameters of the state of connective tissue were determined at the levels of general GAG, their I and III fractions (chondroitin-6-sulfate and heparan sulfate, respectively). In the first group of boars, there was a higher level of I fraction of GAG, that indicated a significant load on the joints' cartilages and the gradual development of destructive processes in them. About the III fraction of GAG, an increasing of their blood content could indicate the reaction of the vascular flow, changes in ventilation of the lungs, the course of anti-inflammatory processes in animals with the appearance of intense physical activity.

Key words: boars, intensity, reproduction, glycosaminoglycans, creatine phosphokinase, lipids. 


\title{
Метаболічний профіль та вміст біополімерів сполучної тканини в сироватці крові кнурів-плідників за різного режиму репродуктивного навантаження
}

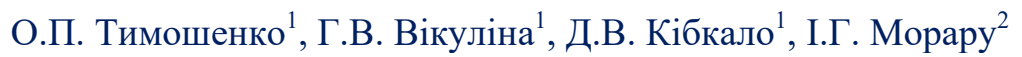 \\ ${ }^{1}$ Харківська державна зооветеринарна академія, м. Харків, Україна \\ 2 “Агроінвестгруп”, м. Одеса, Україна
}

\begin{abstract}
Для встановлення оптимальних параметрів реалізації репродуктивного потенціалу кнурів-плідників потрібно проводити не тільки оиінку його статевої активності та якості сперми, а й ретельно досліджувати метаболічний статус за допомогою лабораторних методів під час диспансеризачії. Біохімічними методами дослідження можсна встановити дисбаланс в обмінах речовин, характер та локалізацію циитолітичних процесів за ступенем активності ензимів у сироватиі крові. Але з метою виявлення запальних чи деструктивних змін у сполучно-тканинних структурах, зокрема опорно-руховому апараті, найбільш інформативними показниками будуть біополімери сполучної тканини - глікопротеїни та протеоглікани. У даній роботі наведені результати комплексного обстеження клінічно здорових кнурів-плідників із різним режимом виробничого використання, до якого увійшов розширений комплекс біохімічних тестів із визначенням рівня глікопротеїнів, хондроїтинсульфатів, загальних глікозаміногліканів та їхніх фракцій. Встановлено, щьо рівень таких показників, як загальний білок та його фракиії, сечовина, активність аспартат- та аланінамінотрансферази, МВ-фракції креатинфосфокінази не мали вірогідних змін. Для кнурів-плідників, що використовувалися у репродуктивних заходах нерегулярно (I група), був показовим більший рівень креатиніну та показників глікозаміногліканограми. У тварин з регулярною технологією використання як плідників (II група) рівень креатиніну та фракиій глікозаміногліканів (ГАГ) був нижчим, але відбувалося підвищення рівня холестеролу, $\beta$-ліпопротеїнів, активності загальної креатинфосфокінази в сироватці крові. Вірогідну різнищю у иих показниках можна пояснити різницею ступеня інтенсивності процесів енергетичного обміну в м'язовій тканині. Адже за довготривалої напруженої роботи скелетних м'язів використовуються не тільки запаси глікогену, а й великого значення набуває використання ліпідів. До того ж зростання холестеролу та $\beta$-ліпопротеїнів може бути наслідком активного їх залучення до синтезу стероїдних гормонів. Підвищення активності загальної креатинфосфокінази у сироватиі крові тварин з інтенсивною технологією використання, найімовірніше, є свідченням важкої фізичної роботи та розвитку деструктивних прочесів у м'язовій тканині (гіперферментемія виявлясться на ранніх стадіях міопатій). Про відсутність саме запальних процесів свідчив незмінений рівень глікопротеїнів сироватки крові, які, як відомо, відносяться до гострофазових тестів. Різниці в показниках стану сполучної тканини визначалися у рівнях загальних ГАГ, їх I та III фракиій (хондроїтин-6-сульфату та гепарансульфату відповідно). У кнурів І групи був більшим рівень I фракиій ГАГ, що вказувало на значне навантаження на хрящі суглобів та поступовий розвиток у них деструктивних процесів. Щодо ІІІ фракиї̈ ГАГ, підвищення ії вмісту в крові могло свідчити про реакиію судинного річщща, зміни у вентиляиії легень, перебіг протизапальних процесів у тварин при появі інтенсивного фізичного навантаження.
\end{abstract}

Ключові слова: кнури, інтенсивність, відтворення, глікозаміноглікани, креатинфосфокіназа, ліпіди

\section{Вступ}

Кнури-плідники є дуже цінними тваринами як з позиції економіки, так і продуктивного використання. Відомо, що $50 \%$ успіху в досягненні максимальних показників заплідненості свиноматок та ефективності осіменіння залежить від якісних показників сперми кнурів-плідників (Harenko et al., 2010). Для збереження статевої активності та здоров'я кнурів у період племінного використання служби необхідно регулювати їхнє навантаження, тобто кількість маток, що ними осіменялися. Велике значення має регулярне використання плідників. За дуже частих садок кнури виснажуються, у них перенапружується нервова система, сперма виробляється 3 незрілими сперміями (Hlopyc'kyj et al., 2012). Дуже рідкі садки, навпаки, знижують статеві рефлекси, спермії у придатку сім'яників старіють, пригнічується їх утворення. Отже, систематичне помірне використання кнурів сприяє підтримці нормального фізіологічного стану та врівноваженого стану нервової системи. Тож $з$ цього приводу в науковій світовій літературі більшість робіт присвячена визначенню відтворної здатності кнурівплідників, вивченню властивостей сперми та впливу на них зовнішніх (клімат, навколишнє середовище, умови їх утримання і годівлі) та внутрішніх (генетич- них) факторів (Kunavongkrit et al., 2005; Pinart \& Puigmulé, 2013; Savić et al., 2013; Knecht et al., 2014). Безсумнівно, умови навколишнього середовища (температура повітря, інсоляція, моціон тощо) та їх порушення можуть провокувати стрес у кнурів і це впливає на виробництво сперматозоїдів (Zasiadczyk et al., 2015). До того ж науковці різних країн досліджують вплив різних біологічно активних речовин на спермопродукцію та якість сперми і на цій основі визначають репродуктивні здатності кнурів-плідників (Horký et al., 2013; Bruveris et al., 2013; Petrujkić et al., 2014) Але, щоб оцінити стан здоров'я тварини, зокрема іiі репродуктивні функції, необхідно проводити всебічне обстеження та насамперед, оцінювати метаболічний профіль. Адже відтворна здатність кнура-плідника та якість сперми залежать від функціонального стану його органів та систем, оцінити який можливо за використання лабораторного дослідження крові тварини.

Відомо, що кнури-плідники досить часто хворіють на внутрішні незаразні хвороби, зокрема серцевосудинні та захворювання опорно-рухового апарату. Однією з найпоширених причин вибраковування ремонтного молодняку, особливо кнурів, є слабкість кінцівок (Rogožarski et al., 2014; Wang et al., 2018). Щорічне вибракування з цієї причини сягає на ком- 
плексах 40\% (Moraru, 2010). Отже, доцільним є проведення досліджень метаболічного профілю різних порід кнурів-плідників залежно від умов утримання, складу раціону та ступеня функціонального навантаження, що стане основою для розробки удосконаленої методики терапевтичної диспансеризації. За даними літератури, доцільно включати визначення рівня загального білка та складових протеїнограми, рівнів сечовини і креатиніну, активності аланін- (АлАТ) і аспартатамінотрансферази (АсАТ), вмісту глікопротеїнів і хондроїтинсульфатів (Timoshenko et al., 2010; Moraru \& Vikulina, 2011). Тому метою роботи стало 3'ясування інформативності розширеного комплексу біохімічних показників, що включає показники стану сполучної тканини, під час диспансерного обстеження кнурів за різного режиму репродуктивного навантаження.

\section{Матеріал і методи досліджень}

Об'єктом дослідження буди кнури-плідники ( $\mathrm{n}=14)$, віком 10-12 місяців, таких порід: Large white $(\mathrm{n}=8)$, Maxter $(\mathrm{n}=2)$, Landras $(\mathrm{n}=2)$ та Pietrain $(\mathrm{n}=2) 3$ різним режимом статевого використання (I група $-\mathrm{n}=7$ нерегулярне репродуктивне використання, II група $-\mathrm{n}=7$ регулярне, інтенсивне репродуктивне використання). Тварин досліджували загальноклінічними методами та проводили відбір зразків крові шляхом пункції орбітального венозного синусу 3 метою отримання сироватки крові. Варто зауважити, що на час проведення дослідів у кнурів за даними клінічних досліджень не виявлено ознак будь-якого захворювання.

Лабораторні дослідження проводили в умовах біохімічної лабораторії Інституту патології хребта та суглобів ім. М.I. Ситенка АМНУ та клінікодіагностичної лабораторії ПП “Алвис-класс" м. Харкова. У сироватці крові визначали: вміст загального білка та його фракцій, активність АлАТ та АсАТ, креатинфосфокінази (КФК) та іiі МВ-фракції, вміст сечовини, креатиніну, холестеролу, фракцій білірубіну, $\beta$-ліпопротеїнів та глюкози уніфікованими методиками (Kamyshnikov, 2004; Vlizlo et al., 2012). Також визначали рівень показників, що характеризують стан сполучної тканини: глікопротеїнів (за методом О.П. Штейнберг та Я.Н. Доценка), загальних хондроїтинсульфатів (ХСТ) - реакцією з риванолом та фракцій глікозаміногліканів (ГАГ) - реакцією 3 резохином (Morozenko \& Leont'jeva, 2016).

Статистичний аналіз даних був здійснений за допомогою можливостей табличного процесору Microsoft Excel та програмного пакету Statsoft Statistica 10.0. Порівняння груп пацієнтів проводили за параметричним критерієм Стьюдента (Glanc, 1998).

\section{Результати}

Встановлено, що рівень глюкози та фракцій білірубіну за середніми показниками достовірно не різнився у групах тварин (табл. 1). На однаковому рівні також перебігав білковий обмін, на що вказують рівні глікопротеїнів, загального білка, його фракцій та продукту кінцевого обміну білка - сечовини (вірогідної різниці між вказаними показниками не знайдено). Активність АсАТ та АлАТ також не різнилася, що вказує на однакову функціональну активність клітин печінки та серцевого м'язу. Останне також підтверджується відсутністю вірогідної різниці показника активності МВ-фракції КФК $(42,43 \pm 6,23$ та 54,00 \pm 6,86 Од/л), що, як відомо, є більш специфічною саме для міокарду. Поряд 3 тим у I групі виявлено вірогідно вищий вміст креатиніну (до 171,52 9,47 мкмоль/л), що у 1,26 разу вище $(\mathrm{P}<0,01)$, та у

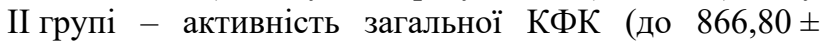
111,01 Од/л), що у 1,62 разу вище $(\mathrm{P}<0,05)$.

Рівень $\beta$-ліпопротеїнів у тварин II групи був у 1,48 разу підвищений порівняно 3 тваринами I групи й сягав значення 48,2 $\pm 2,69$ г/л. Рівень холестеролу також мав більше значення у II групі тварин $(3,20 \pm$ $0,07$ ммоль/л, $\mathrm{P}<0,05)$, що корелює більшим рівнем $\beta$-ліпопротеїнів.

\section{Таблиця 1}

Показники сироватки крові кнурів-плідників за різного режиму репродуктивного навантаження $(\mathrm{M} \pm \mathrm{m})$

\begin{tabular}{lcc}
\hline \multicolumn{1}{c}{ Показники } & I група $(\mathrm{n}=7)$ & II група $(\mathrm{n}=7)$ \\
\hline Глюкоза, ммоль/л & $4,97 \pm 0,18$ & $4,94 \pm 0,08$ \\
Глікопротеїни, г/л & $0,94 \pm 0,01$ & $0,93 \pm 0,03$ \\
Загальний білок, & $72,51 \pm 1,90$ & $75,01 \pm 1,40$ \\
г/л & $46,29 \pm 1,07$ & $45,69 \pm 0,38$ \\
Альбуміни, \% & $8,09 \pm 0,23$ & $8,06 \pm 0,16$ \\
$\alpha_{1}$-глобуліни, \% & $9,46 \pm 0,68$ & $8,53 \pm 0,10$ \\
$\alpha_{2}$-глобуліни, \% & $7,40 \pm 0,29$ & $7,93 \pm 0,10$ \\
В-глобуліни, \% & $28,77 \pm 0,41$ & $29,79 \pm 0,50$ \\
$\gamma$-глобуліни, \% & $7,20 \pm 0,09$ & $6,99 \pm 0,19$ \\
Сечовина, & \\
ммоль/л & & \\
Креатинін, & $171,52 \pm 9,47 * * *$ & $135,83 \pm 6,07$ \\
мкмоль/л & $85,47 \pm 11,77$ & $147,08 \pm 54,59$ \\
АсАТ, Од/л & $58,02 \pm 5,22$ & $63,47 \pm 7,36$ \\
АлАТ, Од/л & $535,06 \pm 50,86$ & $866,80 \pm 111,01 * *$ \\
КФК, Од/л & $54,00 \pm 6,86$ \\
КФК-МВ, Од/л & $42,43 \pm 6,23$ & $48,2 \pm 2,69 * * *$ \\
$\beta$-ліпопротеїни, & $32,6 \pm 1,74$ & \\
Г/л & & \\
Холестерол, & $3,01 \pm 0,05$ & $3,20 \pm 0,07 * *$ \\
ммоль/л & & \\
Білірубін заг., & $9,38 \pm 0,71$ & $8,17 \pm 1,36$ \\
мкмоль/л & \\
Білірубін прямий, \\
мкмоль/л \\
ХСТ, г/л
\end{tabular}


Вірогідно вищим у кнурів I групи був вміст загальних ГАГ та їх III фракції $(13,49 \pm 0,23$ та $1,83 \pm$ 0,18 ум.од., відповідно Р < 0,01). Виявлено тенденцію до збільшення I фракції ГАГ - 7,33 \pm 0,54 ум.од.

\section{Обговорення}

Як відомо, єдиним джерелом енергії для скорочення м'язів служить АТФ. Вона витрачається як в акті скорочення, так і в акті розслаблення м'язів. Під час скорочення м'язів інтенсивність обміну в них збільшується у 100-1000 разів. Підтримання тривалої працездатності м'язів зумовлює постійне відновлення (ресинтез) АТФ з тією ж швидкістю, з якою вона витрачається. Вміст креатинфосфату в м'язі у стані спокою в середньому у п'ять разів більший, ніж АТФ. Запасу креатинфосфату вистачає на роботу м'язів ще протягом не більше ніж 5-6 секунд (для 30-100 скорочень). Тривала м'язова робота забезпечується енергією гліколізу. Для короткотривалої напруженої роботи насамперед використовуються запаси глікогену, а для довготривалого функціонування все більшого значення набуває використання жирів (Tarasenko et al., 2007). Як відомо, утворення креатиніну (кінцевого продукту енергетичного обміну в м'язовій тканині) залежить від маси м'язів та в меншій мірі від маси тіла. У наших дослідженнях встановлено, що у кнурів I групи рівень креатиніну як показника метаболічної активності скелетної мускулатури вищий, ніж у тварин II групи. Це вказує на відсутність постійної енергозабезпеченої роботи м'язів, для якої $\epsilon$ достатнім збагачення м'язових волокон енергією за рахунок креатинфосфату. У II групі кнурів рівень креатиніну нижчий, що свідчить про переважання процесів анаеробного окиснення глюкози під час розпаду глікогену м'язів, адже саме цей процес супроводжує довготривалу фізичну роботу.

У цитоплазмі клітин скелетних м'язів спостерігається висока креатинкіназна активність. Наприклад, у людини активність КФК-ММ у сироватці крові становить 94-96\% від загальної активності КФК, КК-МВ 4-6 \%, КФК-ВВ - активність слідова або не визначається (Chorna \& Vysoc'kyj, 2013). Підвищення активності загальної КФК у сироватці крові за рахунок зростання активності ізоферменту КФК-ММ залежить не тільки від важких фізичних навантажень, а й від розвитку в скелетних м'язах запальних та деструктивних процесів. Підвищення активності загальної КФК у сироватці крові кнурів-плідників II групи, на нашу думку, вказує на те що це може бути наслідком важкої фізичної роботи або поступовим розвитком дистрофічних процесів у скелетній мускулатурі. Також є дані, що звичайні клінічні прояви захворювань м'язів - м'язова слабкість, виснаження та біль - можуть спостерігатися як за міопатій, так і під час порушення іннервації. Багато форм міопатій супроводжуються специфічним зростанням активності КФК у сироватці крові, на відміну від нейрогенних захворювань м'язів, за яких подібні зміни звичайно відсутні. Під час інтерпретації лабораторних даних необхідно враховувати, що найбільш високі величини гіперферментемії вдається виявити на ранніх стадіях міопатій. Пізніше, коли значна частина м'язової тканини вже зазнала патологічних змін та біосинтез КФК у м'язах знижений, активність цього ензиму в сироватці крові також може бути зниженою (Dolgov \& Men'shykov, 2012).

Більше половини холестеролу в організмі (65\%) зосереджено в нервовій системі, сполучній тканині та м'язах (Kamyshnikov, 2004). В організмі виділяють 2 фонду холестеролу: структурний (представлений вільним холестеролом плазматичних мембран) та метаболічно активний (гетерогенний за фракційним складом ефірозв'язаний холестерол; він виявляється, в основному, у ліпопротеїнах плазми крові, корі надниркових залоз, сурфактанті легень). Холестерол, що міститься у складі ліпопротеїнів, використовується для біосинтезу жовчних кислот, стероїдних гормонів, вітаміну $\mathrm{D}_{3}$, утворення нових плазматичних мембран клітин, що будуються (Mejer \& Harvi, 2007). У наших дослідженнях рівні холестеролу та $\beta$-ліпопротеїнів (ліпопротеїнів низької щільності) різнилися за показниками в обох групах. Більший їх рівень був у тварин II групи, що використовуються інтенсивно як плідники. Відомо, що дана фракція ліпопротеїнів відповідає за транспорт холестеролу в тканини. Отже, більші рівні ліпідних показників у тварин II групи, яких використовують інтенсивно у виробництві, спровоковані реакцією периферійних тканин, зокрема м'язової, та активно залучаються до синтезу біологічно активних речовин, таких як стероїдні гормони.

Функціональне значення протеогліканів визначається властивостями ГАГ, які входять до їхнього складу, структурою молекули, взаємовідношеннями їх 3 волокнистими компонентами і полягає передовсім у забезпеченні трофічної функції, яка залежить від іонообмінної активності ГАГ (Tarasenko, 2007). Протеоглікани не лише регулюють ріст і орієнтацію колагенових фібрил, а й стабілізують структуру волокон. Так, ХСТ є первинними центрами ініціації мінералізації кісткової тканини за рахунок здатності зв'язувати іони $\mathrm{Ca}^{2+}$. Оскільки у групах тварин показник II фракції ГАГ (хондроїтин-4-сульфат) був на однаковому рівні, можна, таким чином, виключити наявність патології опорно-рухового апарату, зокрема кісткової тканини, в цих тварин. Але виявлено тенденцію до збільшення I фракції ГАГ (хондроїтин-6сульфат) у I групі кнурів, що зумовлено значним навантаженням на хрящові поверхні суглобів у кнурів та непристосованістю даної групи плідників до інтенсивного навантаження $з$ поступовим розвитком патології суглобів. Щодо III фракції ГАГ (гепарансульфати), вищий їх рівень у сироватці крові кнурів I групи може бути реакцією організму на різкі зміни інтенсивності використання (коли стан спокою переважає над виробничим використанням). Гепарансульфати входять до складу артеріальної стінки, строми печінки, легень, взаємодіють з різними білками, тим самим приймають участь у широкому спектрі фізіологічних процесів, таких як клітинна адгезія, ферментативна регуляція, дія цитокінів та ін. 
(Salmivirta et al., 1996). Тобто підвищення їхнього вмісту в крові тварин може бути наслідком змін артеріального тиску, порушень вентиляції легень, протизапальних процесів тощо.

\section{Висновки}

Встановлено, що у I групі кнурів-плідників за нерегулярного режиму репродуктивного використання відмінностями метаболічного профілю були вищі рівні креатиніну та загальних глікозаміногліканів (за рахунок I та III їх фракцій) порівняно $з$ тваринами II групи. Це $\epsilon$ свідченням таких фізичних навантажень, для яких у скелетній мускулатурі достатнім є перебіг енергетичного обміну за рахунок креатинфосфату. Оскільки у цій групі тварин відсутнє постійне їх репродуктивне використання, поява значного фізичного навантаження при садці впливає на суглоби як статичну систему. Це підтверджується підвищенням рівня I фракції ГАГ - хондроїтин-6-сульфату. У ІІ групі тварин, яких використовували регулярно та інтенсивно як плідників, були вищими активність загальної креатинфосфокінази та рівні показників ліпідного обміну - холестеролу та $\beta$-ліпопротеїнів (порівняно $з$ тваринами I групи). Скелетна мускулатура $є$ динамічною системою і постійні фізичні навантаження можуть супроводжуватися не тільки збільшенням їі об'єму, а й поступовим розвитком деструктивних процесів. Для інтенсивного режиму репродуктивного використання $\epsilon$ необхідною велика кількість енергії, яка вироблятиметься не тільки за рахунок креатинфосфату, а й прискоренням процесів глікогенолізу, гліколізу та ліполізу в міоцитах.

\section{References}

Bruveris, Z., Antane, V., Misane, I., Rimeicans, J., Lusis, I., Auzans, A., \& Stonans, I. (2013). Effects of meldonium on sexual performance, sperm motility, testes morphology and blood biochemical markers in boars. Animal reproduction science, 136(4), 303-309. doi: 10.1016/j.anireprosci.2012.11.007.

Chorna, I.V. \& Vysoc'kyj, I.Ju. (2013). Klinichna enzymologija. Enzymodiagnostyka. Sumy. Sums'kyj derzhavnyj universytet (in Ukrainian).

Dolgov, V.V., \& Men'shikov V.V. (2012). Klinicheskaja laboratornaja diagnostika. Moskva: GJeOTAR-Media (in Russian).

Fedjajeva, A.S. (2018). Udoskonalennja umov utrymannja knuriv zakordonnoi' selekcii', vplyv mocionu na vyrobnyctvo spermy. Visnyk Poltavs'koi' derzhavnoi' agrarnoi' akademii', 1, 153-155. doi: 10.31210/visnyk2018.01.31 (in Ukrainian).

Glanc, S. (1998). Mediko-biologicheskaja statistika. Moskva: Praktika (in Russian).

Harenko, M.I., Homyn, S.P., Krajevs'kyj, A.J., Stefanyk, V.Ju., Harenko, A.M., Voshhenko, I.B., \& Chernenko, AA. (2010). Fiziologija, patologija ta biotehnika vidtvorennja svynej. S. "Kozac'kyj val" (in Ukrainian).
Hlopyc'kyj, V.P., Narizhnyj, O.G., Zasuha, Ju.V., \& Gryshhenko, S.M. (2012). Osoblyvosti vykorystannja knuriv za potokovogo vyrobnyctva svynyny. Naukovyj visnyk Nacional'nogo universytetu bioresursiv i pryrodokorystuvannja Ukrai'ny, 179, 3946 (in Ukrainian).

Horký, P., Jančíková, P., \& Zeman, L. (2013). The effect of a supplement of chromium (picolinate) on the level of blood glucose, insulin activity and changes in laboratory evaluation of the ejaculate of breeding boars. Acta Universitatis Agriculturae et Silviculturae Mendelianae Brunensis, 60(1), 49-56. doi: 10.11118/actaun201260010049.

Kamyshnikov, V.S. (2004). Spravochnik po klinikobiohimicheskim issledovanijam i laboratornoj diagnostike. Moskva: MEDpress-inform (in Russian).

Knecht, D., Środoń, S., \& Duziński, K. (2014). The influence of boar breed and season on semen parameters. South African Journal of Animal Science, 44(1), 1-9. doi: 10.4314/sajas.v44i1.1.

Kunavongkrit, A., Suriyasomboon, A., Lundeheim, N., Heard, T.W., \& Einarsson, S. (2005). Management and sperm production of boars under differing environmental conditions. Theriogenology, 63(2), 657667. doi: 10.1016/j.theriogenology.2004.09.039.

Mejer, D., \& Harvi, Dzh. (2007). Veterinarnaja laboratornaja medicina. Interpretacija i diagnostika. Moskva, Sofion (in Russian).

Moraru, I. (2010). Ekspluatacijni hvoroby knurivplidnykiv. Agroexpert, 6, 56-61 (in Ukrainian).

Moraru, I.G., \& Vikulina, G.V. (2011). Udoskonalennja diagnostychnogo etapu dyspanseryzacii' knurivplidnykiv na suchasnyh promyslovyh kompleksah. Naukovyj visnyk veterynarnoi' medycyny, 8(87), 113116 (in Ukrainian).

Morozenko, D.V., \& Leont'jeva F.S. (2016). Metody doslidzhennja markeriv metabolizmu spoluchnoi' tkanyny u klinichnij ta eksperymental'nij medycyni. Molodyj vchenyj, 2(29), 168-172 (in Ukrainian).

Petrujkić, B.T., Šefer, D.S., Jovanović, I.B., Jovičin, M., Janković, S., Jakovljević, G. \& Anderson, R.C. (2014). Effects of commercial selenium products on glutathione peroxidase activity and semen quality in stud boars. Animal feed science and technology, 197, 194-205. doi: 10.1016/j.anifeedsci.2014.09.001

Pinart, E., \& Puigmulé, M. (2013). Factors affecting boar reproduction, testis function, and sperm quality. In Boar Reproduction. Springer, Berlin, Heidelberg, 109-202. doi: 10.1007/978-3-642-35049-8_4.

Rogožarski, D., Prokić, N., Bojkovski, J., \& Vasiljević, T. (2014). Health Status of Boars Used in Reproduction. Bulletin of the University of Agricultural Sciences \& Veterinary Medicine Cluj-Napoca. Veterinary Medicine, 71(2), 427-431. doi: 10.15835/buasvmenvm: 10694 .

Salmivirta, M., Lidholt, K. \& Lindahl, U. (1996). Heparan sulfate: A piece of information. FASEB J, 10, 12701279. doi: 10.1096/fasebj.10.11.8836040.

Savić, R., Petrović, M., Radojković, D., Radović, Č., Parunović, N., Pušić, M., \& Radišić, R. (2013). Varia- 
bility of ejaculate volume and sperm motility depending on the age and intensity of utilization of boars. Biotechnology in Animal Husbandry, 29(4), 641-650. doi: 10.2298/bah1304641s.

Tarasenko, L.M., Grygorenko, V.K., \& Neporada, K.S. (2007). Funkcional'na biohimija. Vinnycja: Nova Knyga (in Ukrainian).

Timoshenko, O.P., Vikulina, G.V., \& Moraru, I.G. (2010). Metabolichnyj profil' knuriv-plidnykiv riznyh porid. Naukovyj visnyk veterynarnoi' medycyny, 5(78), 174-178 (in Ukrainian).
Vlizlo, V.V. et al. (2012). Laboratorni metody doslidzhen' u biologii', tvarynnyctvi ta veterynarnij medycyni. dovidnyk. L'viv: SPOLOM (in Ukrainian).

Wang, C., Li, J.L., Wei, H.K., Zhou, Y.F., Tan, J.J., Sun, H.Q., \& Peng, J. (2018). Analysis of influencing factors of boar claw lesion and lameness. Animal Science Journal, 89(5), 802-809. doi: 10.1111/asj.12974.

Zasiadczyk, L., Fraser, L., Kordan, W., \& Wasilewska, K. (2015). Individual and seasonal variations in the quality of fractionated boar ejaculates. Theriogenology, 83(8), 1287-1303. doi: 10.1016/j.theriogenology.2015.01.015. 